\title{
High rates of denitrification and nitrous oxide emission in arid biological soil crusts from the Sultanate of Oman
}

\author{
Raeid MM Abed ${ }^{1}$, Phyllis Lam², Dirk de Beer ${ }^{2}$ and Peter Stief ${ }^{2}$ \\ ${ }^{1}$ Biology Department, College of Science, Sultan Qaboos University, Muscat, Sultanate of Oman and \\ ${ }^{2}$ Max-Planck Institute for Marine Microbiology, Bremen, Germany
}

\begin{abstract}
Using a combination of process rate determination, microsensor profiling and molecular techniques, we demonstrated that denitrification, and not anaerobic ammonium oxidation (anammox), is the major nitrogen loss process in biological soil crusts from Oman. Potential denitrification rates were $584 \pm 101$ and $58 \pm 20 \mu \mathrm{mol} \mathrm{N} \mathrm{m} \mathrm{h}^{-1}$ for cyanobacterial and lichen crust, respectively. Complete denitrification to $\mathrm{N}_{2}$ was further confirmed by an ${ }^{15} \mathrm{NO}_{3}^{-}$tracer experiment with intact crust pieces that proceeded at rates of $103 \pm 19$ and $27 \pm 8 \mu \mathrm{mol} \mathrm{N} \mathrm{m} \mathrm{N}^{-2} \mathrm{~h}^{-1}$ for cyanobacterial and lichen crust, respectively. Strikingly, $\mathrm{N}_{2} \mathrm{O}$ gas was emitted at very high potential rates of $387 \pm 143$ and $31 \pm 6 \mu \mathrm{mol} \mathrm{N} \mathrm{m}{ }^{-2} \mathrm{~h}^{-1}$ from the cyanobacterial and lichen crust, respectively, with $\mathrm{N}_{2} \mathrm{O}$ accounting for $53-66 \%$ of the total emission of nitrogenous gases. Microsensor measurements revealed that $\mathrm{N}_{2} \mathrm{O}$ was produced in the anoxic layer and thus apparently originated from incomplete denitrification. Using quantitative PCR, denitrification genes were detected in both the crusts and were expressed either in comparable (nirS) or slightly higher (narG) numbers in the cyanobacterial crusts. Although $99 \%$ of the nirs sequences in the cyanobacterial crust were affiliated to an uncultured denitrifying bacterium, $94 \%$ of these sequences were most closely affiliated to Paracoccus denitrificans in the lichen crust. Sequences of nos $Z$ gene formed a distinct cluster that did not branch with known denitrifying bacteria. Our results demonstrate that nitrogen loss via denitrification is a dominant process in crusts from Oman, which leads to $\mathrm{N}_{2} \mathrm{O}$ gas emission and potentially reduces desert soil fertility.

The ISME Journal (2013) 7, 1862-1875; doi:10.1038/ismej.2013.55; published online 11 April 2013

Subject Category: Geomicrobiology and microbial contributions to geochemical cycles

Keywords: biological soil crust; nitrogen cycle; denitrification; microsensors; stable isotopes; quantitative PCR
\end{abstract}

\section{Introduction}

The availability of nitrogen is one of the major constraints to biological activities in arid ecosystems (Muyi and Caldwell, 1997; Garbauer and Ehleringer, 2000), and thus estimates of the inputs and outputs of nitrogen in deserts is essential to the understanding and future predictions of ecosystem functioning therein. Biological soil crusts (referred to as crusts hereafter), typically covering surface desert soils, greatly influence the nitrogen cycle of arid and semiarid ecosystems (Belnap, 2001). The conversion of atmospheric $\mathrm{N}_{2}$ into ammonium $\left(\mathrm{NH}_{4}^{+}\right)$by crustal diazotrophic cyanobacteria, lichens and heterotrophic bacteria is the dominant source of nitrogen in desert ecosystems (Belnap, 2002; Billings et al.,

Correspondence: RMM Abed, Biology Department, College of Science, Sultan Qaboos University, P.O. Box 36, Al Khoud, Muscat 123, Sultanate of Oman.

E-mail: rabed@mpi-bremen.de

Received 16 December 2012; revised 28 February 2013; accepted 2 March 2013; published online 11 April 2013
2003; Yeager et al., 2004; Veluci et al., 2006; Abed et al., 2010), particularly where rainfall and anthropogenic nitrogen inputs are minimal. Although much progress in nitrogen cycling research in crusts has so far been made with respect to nitrogen inputs via nitrogen fixation, nitrogen loss processes have received much less attention. Nitrogen is lost as gaseous products (that is, $\mathrm{N}_{2}, \mathrm{~N}_{2} \mathrm{O}$ and $\mathrm{NO}$ ) through the stepwise reduction of nitrate by denitrification $\left(\mathrm{NO}_{3}^{-} \rightarrow \mathrm{NO}_{2}^{-} \rightarrow \mathrm{NO} \rightarrow \mathrm{N}_{2} \mathrm{O} \rightarrow \mathrm{N}_{2}\right)$, the combination of ammonium and nitrite by anammox $\left(\mathrm{NH}_{4}^{+}+\mathrm{NO}_{2}^{-} \rightarrow\right.$ $\mathrm{N}_{2}$ ), nitrifier-denitrification by ammonia-oxidizers under oxygen stress or, to a lesser extent, as a byproduct during aerobic ammonia oxidation (Ritchie and Nicholas, 1972; Poth, 1986; Wrage, et al., 2001; Schmidt et al., 2004; McNeill and Unkovich, 2007; Santoro et al., 2011). Denitrification and anammox have been recognized as the major nitrogen loss mechanisms in many environments, including freshwater, marine as well as terrestrial ecosystems (Seitzinger, 1988; Peterjohn and Schlesinger, 1991; Kuypers et al., 2003, 2005; Ward et al., 2009; Humbert et al., 2010; Lam and Kuypers, 2011), but 
their potential occurrence and significance in crusts remains poorly understood. Although crusts have been shown to emit $\mathrm{N}_{2} \mathrm{O}$ and $\mathrm{NO}$ with amounts dependent on season and $\mathrm{N}_{2}$-fixation rates (Barger et al., 2005; Crenshaw et al., 2008), it was not clear which process was responsible for the production of these gases. Rate measurements were performed on crusts from Colorado Plateau, Mojave, Sonoran and Chihuahuan deserts in the United States, and all of them displayed extremely low rates of denitrification and anammox, while ammonia oxidation rates in these crusts were comparable with $\mathrm{N}_{2}$-fixation rates (Johnson et al., 2005, 2007; Strauss and Day, 2012). Subsequent nitrogen budget calculations suggested that these crusts act as a net nitrogen source. It is not known if such perceived imbalance is widespread among desert ecosystems in other parts of the globe, and this has prompted our current study.

With deserts covering approximately one-third of the Earth's land surface (ca. 44 million $\mathrm{km}^{2}$ ), the subtropical Arabian Desert covers almost the entire Arabian Peninsula and is considered as the fourth largest desert (ca. 2.3 million $\mathrm{km}^{2}$ ) in the world (Allan and Warren, 1993). Nevertheless, crusts covering the surface soils of these deserts remain understudied. With respect to nitrogen cycle, crusts from Oman were recently shown to fix nitrogen at rates $\left(39.4 \pm 13.4-58.5 \pm 2.6 \mu \mathrm{mol} \quad \mathrm{C}_{2} \mathrm{H}_{2} \mathrm{~m}^{-2} \mathrm{~h}^{-1}\right.$ as determined by acetylene reduction assay) comparable with those measured in other desert ecosystems (Abed et al., 2010). However, no information is available on other nitrogen transformation processes, despite their apparent paramount importance in regulating nitrogen balance within these systems. A primary unique characteristic of arid and semiarid desert ecosystems is the episodic nature of water availability, which has significant consequences for carbon and nitrogen cycling. Biological processes (such as respiration, photosynthesis and nitrogen fixation) become active within seconds to a few hours after wetting (Isichei, 1980; Belnap, 1995; Garcia-Pichel and Belnap, 1996; Gao et al., 1998; Qiu and Gao, 1999; Issa et al., 2001; Austin et al., 2004; Qiu et al., 2004). As a consequence of the high respiration activities, oxygen becomes limiting very rapidly, resulting in the formation of anoxic microsites (Garcia-Pichel and Belnap, 1996) and thereby conditions suitable for anaerobic processes. Indeed, a recent study demonstrated the occurrence of the strictly anaerobic methanogenesis process in crusts from the Negev Desert, even when incubated under natural oxic conditions (Angel et al., 2011). Similarly, such anoxic conditions would be conducive to denitrification and anammox, which we hypothesize to be the key nitrogen loss processes in crusts that become active after precipitation events, taking advantage of the developed anoxic conditions and the readily available organic matter produced by photosynthesis.

To test this hypothesis, we measured denitrification and anammox rates under completely anoxic conditions, as well as in intact crusts for denitrification only, in two types of crusts-cyanobacteria- and lichen-dominated-from the desert of Oman. These rates were determined by using the acetylene inhibition technique and ${ }^{15} \mathrm{~N}$-labeling experiments. Microsensor measurements were also made to locate denitrification activity and the concomitant $\mathrm{N}_{2} \mathrm{O}$ emission in intact pieces of crusts with and without acetylene addition. Potential rates of ammonium oxidation were measured to reveal the contribution of nitrification to the nitrate pool in the crusts and to the production of $\mathrm{N}_{2} \mathrm{O}$ gas. A suite of key functional genes in nitrogen cycling were quantified at both gene abundance and expression levels by using quantitative PCR (qPCR) and reverse transcription qPCR (RT-qPCR), whereas the diversity of selected biomarker genes were further analyzed.

\section{Materials and methods}

\section{Samples origin and site description}

The topmost $1-2 \mathrm{~cm}$ of cyanobacteria- (free of symbiotic fungi) and lichen- (composite organisms consisting of a symbiotic relationship between a fungus and a photosynthetic partner, usually either cyanobacteria or microalgae)-dominated crusts, were collected from Wadi Al-Khoud, northern Oman $\left(23^{\circ} 04.595^{\prime} \mathrm{N}, 58^{\circ} 09.055^{\prime} \mathrm{E}\right)$. The site is surrounded by low limestone hills and the surface is covered with small- to medium-sized gravels. Rainfall occurs in the area between 2 and 5 times a year, with a mean annual rainfall of ca. $86.2 \mathrm{~mm}$ from November to April. Temperature ranges between 47 and $50{ }^{\circ} \mathrm{C}$ in the summer and as low as $12{ }^{\circ} \mathrm{C}$ in the winter. Both cyanobacteria- and lichendominated crusts contained more sand (49-50.7\%) than silt and clay (Table 1). The $\mathrm{pH}$ of the two crust types ranged between 7.25 and 7.45 , indicating a slight alkalinity of the crusts, and the cyanobacterial crusts had a significantly lower electrical

Table 1 Characteristics of the two crust types

\begin{tabular}{|c|c|c|c|c|c|c|c|c|c|}
\hline \multirow[t]{2}{*}{ Crust type } & \multicolumn{4}{|c|}{ Soil texture } & \multirow[t]{2}{*}{$p H$} & \multirow[t]{2}{*}{$E C(d S m)$} & \multicolumn{2}{|c|}{$\mathrm{NO}_{3}^{-}\left(\mu \mathrm{molg}^{-1}\right)$} & \multirow{2}{*}{$\frac{\mathrm{NH}_{4}^{+}\left(\mu \mathrm{molg} \mathrm{g}^{-1}\right)}{P W}$} \\
\hline & Silt & Clay & Sand & Texture & & & $P W$ & IC & \\
\hline Cyanobacterial crust & 39.3 & 11.7 & 49 & Loam & 7.45 & 268 & $0.79 \pm 0.39$ & $0.22 \pm 0.09$ & $0.11 \pm 0.07$ \\
\hline Lichen crust & 35.6 & 13.7 & 50.7 & Loam & 7.25 & 354 & $0.62 \pm 0.28$ & $0.17 \pm 0.07$ & $0.12 \pm 0.04$ \\
\hline
\end{tabular}

Abbreviations: EC, electrical conductivity; IC, intracellular; PW, pore water. 
conductivity than the lichen crusts (Table 1). The samples were collected in May 2011, kept dry in plastic boxes and shipped to the Max-Planck Institute, Bremen, Germany where all incubations were performed within 3 months after collection. The last precipitation event before sampling was on 22 January 2011.

\section{Determination of denitrification rates}

Two types of rate measurements were made in order: (1) to assess the maximum potential of nitrogenous gas production by denitrification under ideal conditions (hereafter referred to as potential rates), and (2) to estimate the rate of complete denitrification to $\mathrm{N}_{2}$ in intact crusts.

Potential denitrification rates (that is, the maximum rates under fully anoxic conditions without limitation by nitrate availability and diffusive solute transport) were measured in slurry incubations of crusts by using the acetylene inhibition technique (Sørensen, 1978). The addition of acetylene inhibits the last step of denitrification (that is, the conversion of $\mathrm{N}_{2} \mathrm{O}$ to $\mathrm{N}_{2}$ ) and thus results in the accumulation of $\mathrm{N}_{2} \mathrm{O}$. Crust samples (2-3g each) were incubated in 110-ml glass bottles filled with $30 \mathrm{ml}$ sterile anoxic distilled $\mathrm{H}_{2} \mathrm{O}$ (bubbled with helium gas for $15 \mathrm{~min}$ ) amended with $25 \mu \mathrm{M} \mathrm{NO}-$, thus leaving a headspace volume of $80 \mathrm{ml}$. Each bottle was wrapped with an aluminum foil, to prevent $\mathrm{O}_{2}$ production by photosynthesis, and sealed gas-tight with a rubber stopper, through which it was purged with $\mathrm{N}_{2}$ gas for around $10 \mathrm{~min}$. Also, $10 \%$ of the headspace volume was replaced by acetylene, and the bottles were shaken on a plate shaker at 150 r.p.m. Gas samples $(1 \mathrm{ml}$ each) were drawn from the headspace using a gastight syringe at different time intervals (that is, $5 \mathrm{~min}, 2,4,6$ and $8 \mathrm{~h}$ ) and injected into gas-tight sample vials ( $3 \mathrm{ml}$ exetainers, Labco, Ceredigion, Wales, UK) pre-flushed with $\mathrm{N}_{2} \cdot \mathrm{N}_{2} \mathrm{O}$ concentrations in the exetainers were then measured on a gas chromatograph equipped with a ${ }^{63} \mathrm{Ni}$ electroncapture detector (GC 7890; Agilent Technologies, Boeblingen, Germany). The linear increase in $\mathrm{N}_{2} \mathrm{O}$ concentration observed between 4 and $8 \mathrm{~h}$ of incubation was used to calculate the denitrification rate per $\mathrm{cm}^{2}$ of crust. The weight of crusts was converted to area unit by using a factor that was obtained after weighing 20 crust pieces of $1 \mathrm{~cm}^{2}$ surface area each. An equivalent series of crust pieces was incubated without the addition of acetylene to quantify the potential rate of $\mathrm{N}_{2} \mathrm{O}$ emission. All incubations were run in six replicates. Additional incubations without nitrate and with autoclaved crust pieces served as negative controls.

Denitrification rates were determined in intact crust pieces with vertical oxygen concentration gradients maintained by photosynthesis and respiration and with solute transport governed by diffusion, thus more likely resembling natural conditions. Crust pieces (3-4 g each) were incubated with $25 \mu \mathrm{M}{ }^{15} \mathrm{NO}_{3}^{-}$in an experimental setup similar to the one described above with few modifications. At the beginning of the experiment, the headspace of the bottles was adjusted to $80 \%$ helium $(\mathrm{He})$ and $20 \%$ oxygen $\left(\mathrm{O}_{2}\right)$ to allow $\mathrm{O}_{2}$ gradients to develop in the crust pieces. The bottles were incubated at $26^{\circ} \mathrm{C}$, in the light without shaking. Gas samples ( $3 \mathrm{ml}$ each) were drawn from the headspace at different time intervals and injected into 6-ml exetainers that were completely filled with He-saturated $\mathrm{dH}_{2} \mathrm{O}$. After injection of the gas sample into the exetainer, $100 \mu \mathrm{l}$ $50 \%$ zinc chloride $\left(\mathrm{ZnCl}_{2}\right)$ was added to stop biological activity. All incubations were run in triplicates and autoclaved crust pieces served as negative controls. The excess concentrations of ${ }^{29} \mathrm{~N}_{2}$ and ${ }^{30} \mathrm{~N}_{2}$ in the headspace were derived from the ${ }^{29} \mathrm{~N}_{2}:{ }^{28} \mathrm{~N}_{2}$ and ${ }^{30} \mathrm{~N}_{2}:{ }^{28} \mathrm{~N}_{2}$ ratios determined by gas chromatography-isotope ratio mass spectrometry (GC-IRMS; VG Optima; Isotech, Merseyside, UK). Due to the unexpectedly high background concentrations of ${ }^{14} \mathrm{NO}_{3}^{-}$in the dry crusts (Table 1), the mole fraction of ${ }^{15} \mathrm{NO}_{3}^{-}\left(\mathrm{F}_{15}\right)$ was as low as $20-26 \%$. Thus, random isotope pairing in the denitrification process was expected to produce 5.7-8 times more ${ }^{29} \mathrm{~N}_{2}$ than ${ }^{30} \mathrm{~N}_{2}$ (Nielsen, 1992). Accordingly, the ${ }^{29} \mathrm{~N}_{2}$ time-series data were of much better quality than the ${ }^{30} \mathrm{~N}_{2}$ time-series data and consequently were used to calculate the production rate of ${ }^{28} \mathrm{~N}_{2}+{ }^{29} \mathrm{~N}_{2}+{ }^{30} \mathrm{~N}_{2}$ $\left(R_{N 2 \text { tot }}\right)$ from the production rate of ${ }^{29} \mathrm{~N}_{2}\left(\mathrm{R}_{29 \mathrm{~N} 2}\right)$ as follows (Nielsen, 1992):

$$
\begin{aligned}
R_{N 2 t o t}= & R_{29 N 2} \times\left(\left(F_{15}^{2}+F_{15} \times\left(100-F_{15}\right) \times 2\right.\right. \\
& \left.\left.+\left(100-F_{15}\right)^{2}\right) /\left(F_{15} \times\left(100-F_{15}\right) \times 2\right)\right)
\end{aligned}
$$

This calculation method was justified because anammox rates were not detectable (see Results) and therefore ${ }^{29} \mathrm{~N}_{2}$ production exclusively originated from denitrification. $\mathrm{R}_{29 \mathrm{~N} 2}$ was derived from the linear increase in ${ }^{29} \mathrm{~N}_{2}$ concentration observed between 4 and $8 \mathrm{~h}$ of incubation, and $\mathrm{R}_{\mathrm{N} 2 \text { tot }}$ was then expressed per $\mathrm{cm}^{2}$ of crust. $\mathrm{F}_{15}\left(\mathrm{NO}_{3}^{-}\right)$was determined from the size of the initial nitrate pool in the dry crust, which was measured after suspending an additional series of pre-weighed crust pieces in $3 \mathrm{ml}$ MilliQ $\mathrm{dH}_{2} \mathrm{O}$, immediately followed by centrifugation at $1500 \mathrm{~g}$ for $10 \mathrm{~min}$ and analysis of $\mathrm{NO}_{\mathrm{x}}^{-}$in the supernatant with the $\mathrm{VCl}_{3}$ reduction assay (Braman and Hendrix, 1989) on a $\mathrm{NO}_{\mathrm{x}}$ analyzer (CLD 86; EcoPhysics, Munich, Germany). Additionally, the intracellular $\mathrm{NO}_{3}^{-}$pool present in the dry crusts was quantified by subjecting freshly wetted crust pieces to three freeze-thaw cycles $\left(-180^{\circ} \mathrm{C}\right.$ vs $\left.+90^{\circ} \mathrm{C}\right)$ to make vacuolated cells burst and release their cellular contents into the medium (Kamp et al., 2011).

\section{Determination of anammox rates}

To check for the occurrence of anaerobic ammonium oxidation (anammox), crust samples were incubated in $30 \mathrm{ml}$ sterile MilliQ $\mathrm{dH}_{2} \mathrm{O}$ amended with $25 \mu \mathrm{M}$ 
${ }^{15} \mathrm{NH}_{4} \mathrm{Cl}$ and $25 \mu \mathrm{M} \mathrm{Na}{ }^{14} \mathrm{NO}_{2}^{-}$in 110 -ml glass bottles. The bottles were flushed with $\mathrm{He}$ for $10 \mathrm{~min}$ to create completely anoxic conditions, wrapped with aluminum foil to prevent $\mathrm{O}_{2}$ production by photosynthesis and incubated at $26^{\circ} \mathrm{C}$ on a plate shaker (100 r.p.m.). Gas samples (2.5 ml each) from the headspace were collected at different time intervals and transferred into 6-ml exetainers filled completely with He-saturated water. After injection of the gas sample into the exetainer, $100 \mu \mathrm{l} 50 \% \mathrm{ZnCl}_{2}$ was added to stop any biological activity. The excess concentration of ${ }^{29} \mathrm{~N}_{2}$ in the headspace was determined from the ${ }^{29} \mathrm{~N}_{2}:{ }^{28} \mathrm{~N}_{2}$ ratio by GC-IRMS. All incubations were run in triplicates and autoclaved crust pieces served as negative controls. To determine $\mathrm{F}_{15}\left(\mathrm{NH}_{4}^{+}\right)$, the size of the initial $\mathrm{NH}_{4}^{+}$pool in the dry crusts was measured in the same supernatants as used for background nitrate measurements as previously described (Kempers and Kok, 1989). $\mathrm{F}_{15}\left(\mathrm{NH}_{4}^{+}\right)$was $65 \%$ and $64 \%$ in the cyanobacterial and lichen crust incubations, respectively.

\section{Potential ammonia oxidation rates}

Potential rates of ammonia oxidation, the first step in nitrification, in crusts were measured as previously described (Stief and de Beer, 2006), to allow budget calculations of $\mathrm{N}$ input and output processes. Briefly, pre-weighed crust pieces (2-3 g each) were slurried in $30 \mathrm{ml}$ sterile MilliQ $\mathrm{dH}_{2} \mathrm{O}$ in 110 -ml glass bottles. For the measurement of ammonia oxidation, the medium contained $25 \mu \mathrm{M}$ ammonium sulfate $\left(\left(\mathrm{NH}_{4}\right)_{2} \mathrm{SO}_{4}\right)$ and $20 \mathrm{~mm}$ sodium chlorate $\left(\mathrm{NaClO}_{3}\right)$ that inhibits nitrite oxidation (that is, the second step of nitrification (Belser and Mays, 1980)). The rate of ammonium oxidation can then be inferred from the linear increase in nitrite $\left(\mathrm{NO}_{2}^{-}\right)$concentration during the incubation. This assumes that $\mathrm{NH}_{4}^{+}$ is quantitatively converted to $\mathrm{NO}_{2}^{-}$rather than $\mathrm{N}_{2} \mathrm{O}$, which was justified here because our microsensor measurements confirmed the absence $\mathrm{N}_{2} \mathrm{O}$ production in the oxic layer of the crusts. All bottles were placed on a multiple stirrer and stirred gently at 100 r.p.m. throughout the incubation. To ensure non-limiting $\mathrm{O}_{2}$ availability, the medium was purged with air using a glass pipette connected to an air pump. Subsamples of the slurry $(2 \mathrm{ml}$ each) were collected after $5 \mathrm{~min}, 2,4,6$ and $8 \mathrm{~h}$ and were immediately frozen at $-20^{\circ} \mathrm{C}$ until analyzed. At the end of the experiment, all samples were thawed and centrifuged at 5000 r.p.m. for $10 \mathrm{~min}$ to remove soil particles. In the particle-free water samples, $\mathrm{NO}_{2}^{-}$ was analyzed using the sodium iodide (NaI) reduction assay (Yang et al., 1997) on a $\mathrm{NO}_{\mathrm{x}}$ analyzer (CLD 86; Eco-Physics). All incubations were run in triplicates at $26^{\circ} \mathrm{C}$, and autoclaved crust pieces served as negative controls.

\section{Microsensor measurements}

Crust pieces were immobilized in petri dishes using modeling clay and then wetted by the addition of sterile MilliQ $\mathrm{dH}_{2} \mathrm{O}$. Oxygen and $\mathrm{N}_{2} \mathrm{O}$ microprofiling was started immediately after wetting. Oxygen profiles were measured in the light and in the dark, while $\mathrm{N}_{2} \mathrm{O}$ profiles were measured in the light only. The profiles were measured at $100 \mu \mathrm{m}$ steps using Clark-type sensors with an internal reference and a guard cathode (Revsbech, 1989; Andersen et al., 2001). The $\mathrm{O}_{2}$ sensor was calibrated at a temperature of $26^{\circ} \mathrm{C}$ by taking the readings in the anoxic layer of a piece of crust and in the fully aerated MilliQ $\mathrm{dH}_{2} \mathrm{O}$ (Revsbech, 1989). The $\mathrm{N}_{2} \mathrm{O}$ sensor was calibrated by taking several readings after the addition of aliquots of an $\mathrm{N}_{2} \mathrm{O}$-saturated stock solution to $100 \mathrm{ml}$ MilliQ $\mathrm{dH}_{2} \mathrm{O}$, thereby covering a concentration range of $0-112 \mu \mathrm{M} \quad \mathrm{N}_{2} \mathrm{O}$. Microprofiles were measured using an automated setup controlled by a computer (Polerecky et al., 2007). Microsensor positioning with $1 \mu \mathrm{m}$ precision was facilitated by a VT-80 linear positioner (Micros, Eschbach, Germany) equipped with a DC motor (Faulhaber, Schoenaich, Germany). The microsensors were connected to fast-responding picoamperemeters and the signals were collected using a data acquisition device (DAQPAD6015, National Instruments, Munich, Germany). Areal rates or fluxes of $\mathrm{O}_{2}$ and $\mathrm{N}_{2} \mathrm{O}$ production were calculated from the linear concentration gradients that developed in the crust pieces using the Fick's law of diffusion. The diffusion coefficients of $\mathrm{O}_{2}$ $\left(2.49 \times 10^{-9} \mathrm{~m}^{2} \mathrm{~s}^{-1}\right)$ and $\mathrm{N}_{2} \mathrm{O}\left(2.40 \times 10^{-9} \mathrm{~m}^{2} \mathrm{~s}^{-1}\right)$ at $26{ }^{\circ} \mathrm{C}$ in water were converted to effective diffusivities in the crusts using a porosity value of 0.6 according to Ullman and Aller (1982).

\section{qPCR and expression of functional genes}

Cyanobacterial and lichen crust samples were subjected to DNA extraction using the PowerBiofilm DNA isolation kit (MOBIO laboratories, Inc., Carlsbad, CA, USA) according to the manufacturer's instructions. qPCR was performed to target key functional genes in the first two steps in denitrification: nitrate reduction (narG and napA encoding membrane-bound and periplasmic nitrate reductases, respectively) and nitrite reduction (nirS encoding cytochrome $c d_{1}$-containting nitrite reductase); as well as that for both archaeal and bacterial ammonia oxidation ( $a m o A$ encoding the ammonia monooxygenase subunit A) using previously described primers (Table 3) and protocols (Lam et al., 2009). All qPCR reactions were run on an iCycler iQ Real-Time PCR Detection System equipped with iQ5 software (Bio-Rad, Munich, Germany) and with the PowerSYBR Green PCR Master Mix (Applied Biosystems, Darmstadt, Germany). The copy number of the genes was calculated after correcting for the concentration and dilution factors and are presented as copy number per g of crust (Table 3).

The expression of narG and nirS was additionally followed in both the crust types after $5 \mathrm{~min}, 2,4,6$ and $8 \mathrm{~h}$ of wetting with sterile water. The wet pieces 
were incubated in plastic petri dishes at $26^{\circ} \mathrm{C}$ under light. The mRNA was first extracted from the crust samples using the PowerBiofilm RNA isolation kit (MOBIO laboratories, Inc.) according to the manufacturer's instructions. RNA was reverse-transcribed using Superscript III First-Strand Synthesis Master Mix (Invitrogen, Darmstadt, Germany) with narG and nirS-specific antisense primers. The cDNA was then treated with RNaseH (Ambion, Darmstadt, Germany, Applied Biosystems) at $37^{\circ} \mathrm{C}$ for $20 \mathrm{~min}$, immediately kept on ice for $1 \mathrm{~min}$ and then diluted 2.5 times with nuclease-free water. Subsequent qPCRs were performed with the obtained cDNA as described above. DNA contamination in RNA extracts were also checked and ruled out by performing parallel qPCRs directly with the RNA extracts.

\section{Pyrosequencing of nirS and nos $Z$}

Purified DNA extracts from both the cyanobacterial and lichen crusts were submitted to the Research and Testing Laboratory (RTL; Lubbock, TX, USA) for tag-pyrosequencing of amplified gene fragments of nirS, along with nos $Z$ (nitrous oxide reductase encoding gene) which is a biomarker gene for the last step of denitrification. Tag-encoded FLX amplicon pyrosequencing (bTEFAP) was performed as described before (Dowd et al., 2008a,b) using the GS FLX titanium sequencing kit XLR70, Roche Applied Science (Indianapolis, IN, USA). One-step PCR was conducted with a mixture of hot-start and hot-start high-fidelity Taq polymerases along with primers specific for either nirS or nosZ. The bTEFAP sequencing was performed according to the RTL protocols (www.researchandtesting.com). Obtained sequences were trimmed, low-quality ends and tags were removed and were checked for chimeras using custom software (Dowd et al., 2008b) and the Black Box Chimera Check software B2C2 (http:// www.researchandtesting.com/B2C2.html). Sequences shorter than $250 \mathrm{bp}$ were excluded from further analysis. The program MUSCLE was used for unstructured multiple sequence alignment using non-default parameters -maxiters 2, -diags, which were shown to minimize alignment expansion in short hypervariable tags (Edgar, 2004). High-quality reads were then clustered based on $\geqslant 95 \%$ sequence identity into operational taxonomic units (OTUs) by using the Mothur software (Schloss et al., 2009). Due to the large number of sequences, Mothur was used to create a set of unique sequences, representative of each OTU (at 5\% cutoff) via the getotu.rep command. These sequences were searched against public databases with BLAST (Altschul et al., 1997) to verify their affiliation with the respective genes, and detailed sequence analyses were conducted with the ARB software package (Ludwig et al., 2004). Based on amino acids translated from nirS and nos $Z$ genes, these sequences were aligned to our own databases that consist of all publicly available sequences for both the genes as of July 2012 (except for a few environmental Metagenomes). Sequences that were of low quality and could not be aligned properly were omitted. Phylogenetic affiliations of the crust sequences were determined via maximum parsimony with the quick-add search function in ARB against a consensus tree that has been constructed with all sequences in the database based on maximum likelihood, parsimony and distance matrix algorithms. For clarity reasons, only the crust sequences along with their immediate relatives are shown here in this paper.

\section{Results}

Denitrification and anammox rates

The maximum potential of nitrogenous gas production by denitrification was measured from anoxic slurry incubations with acetylene inhibition technique, while complete denitrification to $\mathrm{N}_{2}$ under more natural conditions was assessed by ${ }^{15} \mathrm{~N}$-tracer experiments with intact crust pieces. The potential rate measurements showed that denitrification started in both the cyanobacteria- and lichendominated crusts within the first $2 \mathrm{~h}$ of incubation under wet and anaerobic conditions (Figure 1a). The accumulation of $\mathrm{N}_{2} \mathrm{O}$ in the incubation bottles, indicative of denitrification activity in the crusts, accelerated with time, until nearly linear increases were observed between 4 and $8 \mathrm{~h}$ of incubation. Although the temporal dynamics were identical for either crust type, the potential denitrification activity was considerably higher in the cyanobacterial crust than in the lichen crust (Figure 1a, Table 2). The potential rates of total denitrification (that is, including the production of both $\mathrm{N}_{2}$ and $\mathrm{N}_{2} \mathrm{O}$ ) calculated for the 4-8-h time interval were $584 \pm 101$ and $58 \pm 20 \mu \mathrm{mol} \mathrm{N} \mathrm{m}{ }^{-2} \mathrm{~h}^{-1}$ for cyanobacterial and lichen crusts, respectively (Table 2). Spontaneous $\mathrm{N}_{2} \mathrm{O}$ emission from the crusts (that is, $\mathrm{N}_{2} \mathrm{O}$ emission in the absence of acetylene inhibition) was substantial in either crust type (Figure 1b). $\mathrm{N}_{2} \mathrm{O}$ emission showed the same temporal dynamics as potential denitrification and reached a rate of $387 \pm 143 \mu \mathrm{mol} \mathrm{Nm}^{-2} \mathrm{~h}^{-1}$ in the cyanobacterial crust, but was only $31 \pm 6 \mu \mathrm{mol} \mathrm{N} \mathrm{m} \mathrm{N}^{-2} \mathrm{~h}^{-1}$ in the lichen crust during the 4-8-h time interval (Table 2). Consequently, the relative share of $\mathrm{N}_{2} \mathrm{O}$ emission from the total emission of nitrogenous gases was as high as $66 \%$ and $53 \%$ for the cyanobacterial and lichen crust, respectively. In the killed controls, neither denitrification activity nor $\mathrm{N}_{2} \mathrm{O}$ emission was observed (Figures 1a and b).

The rate measurements with ${ }^{15} \mathrm{NO}_{3}^{-}$added as a tracer in intact crusts confirmed the occurrence of complete denitrification to $\mathrm{N}_{2}$ (Figure 2). The accumulation of $\mathrm{N}_{2}$ in the incubation bottles (as derived from the accumulation of ${ }^{29} \mathrm{~N}_{2}$, see Materials and methods) followed the same temporal dynamics 


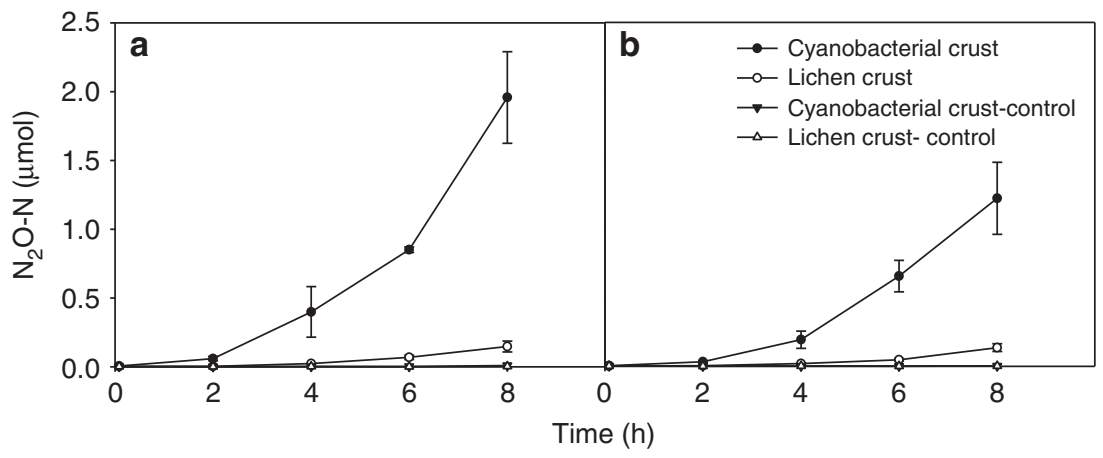

Figure 1 Potential denitrification activity, measured as $\mathrm{N}_{2} \mathrm{O}-\mathrm{N}$ production over time, in slurry incubations of cyanobacterial and lichen crusts amended with $25 \mu \mathrm{MO}_{3}^{-}$and with (a) or without (b) acetylene inhibition of the last step of denitrification. The linear increase in $\mathrm{N}_{2} \mathrm{O}$ concentration observed between 4 and $8 \mathrm{~h}$ of incubation was used to calculate the rates of complete (a) and incomplete (b) denitrification per $\mathrm{cm}^{2}$ of crust. Error bars represent \pm s.d. $(n=6)$. Additional incubations without nitrate and with autoclaved crust pieces served as negative controls.

as observed for the potential rate measurements of denitrification and $\mathrm{N}_{2} \mathrm{O}$ emission but reached lower concentrations (Figures 1 and 2). Measurement of the background ${ }^{14} \mathrm{NO}_{3}^{-}$concentrations at the beginning of the incubation (Table 1) unexpectedly revealed that the mole fraction of ${ }^{15} \mathrm{NO}_{3}^{-}$was as low as $20-26 \%$. Rates of denitrification in intact crusts corrected for these mole fractions were $103 \pm 19$ and $27 \pm 8 \mu \mathrm{mol} \mathrm{N} \mathrm{m} \mathrm{N}^{-2} \mathrm{~h}^{-1}$ for the cyanobacterial and lichen crust, respectively, during the 4-8-h time interval (Table 2). In the killed controls, denitrification activity was not observed (Figure 2).

The anammox process was not detectable in either crust type using ${ }^{15} \mathrm{NH}_{4}^{+}$incubations at mole fractions of $64-65 \%$, as the production of ${ }^{29} \mathrm{~N}_{2}$ was not significantly different from zero for both the living and killed crusts (data not shown).

\section{Ammonia oxidation rates}

Measurements of the potential rate of ammonia oxidation showed an immediate recovery in both the crust types after the addition of water and ammonium (Figure 3). The concentration of $\mathrm{NO}_{2}^{-}$ increased continuously over time and corresponded to ammonia oxidation rates of $15 \pm 2$ and $11 \pm 5 \mu \mathrm{mol}$ $\mathrm{N} \mathrm{m}^{-2} \mathrm{~h}^{-1}$ in the cyanobacterial and lichen crusts, respectively (Table 2). The killed controls did not produce $\mathrm{NO}_{2}^{-}$(Figure 3).

\section{Microsensor profiles}

Microsensor measurements revealed $\mathrm{O}_{2}$ penetration depths of up to $2 \mathrm{~mm}$ in the light in both the crust types, below which the crusts were anoxic (Figure 4a). Oxygen profiles reached steady state after ca. 2 and $3.5 \mathrm{~h}$ of water addition and then revealed fluxes of 2.01 and $4.17 \mathrm{mmol} \mathrm{O}_{2} \mathrm{~m}^{-2} \mathrm{~h}^{-1}$ out of the cyanobacterial and lichen crusts, respectively. In the dark, the crusts turned anoxic within the top $0.5 \mathrm{~mm}$ (Figure 4a, only shown for the cyanobacterial crust). The corresponding $\mathrm{O}_{2}$ fluxes into the crusts were 1.20 and $1.25 \mathrm{mmol} \mathrm{O}_{2} \mathrm{~m}^{-2} \mathrm{~h}^{-1}$
Table 2 Rates calculated from linear concentration increases during $4-8 \mathrm{~h}$ of slurry incubation of crusts and fluxes calculated from microsensor profiles in intact crust pieces (in $\mu \mathrm{mol} \mathrm{N} \mathrm{m}^{-2} \mathrm{~h}^{-1}$ )

\begin{tabular}{lcc}
\hline Process & $\begin{array}{c}\text { Cyanobacterial } \\
\text { crust }\end{array}$ & $\begin{array}{c}\text { Lichen } \\
\text { crust }\end{array}$ \\
\hline Total denitrification & $584 \pm 101$ & $58 \pm 20$ \\
$\left(\mathrm{~N}_{2} \mathrm{O}+\mathrm{N}_{2}\right)^{\mathrm{P}}$ & $387 \pm 143$ & $31 \pm 6$ \\
$\mathrm{~N}_{2} \mathrm{O}$ emission $\left(\mathrm{N}_{2} \mathrm{O}\right)^{\mathrm{P}}$ & $197 \pm 175$ & $27 \pm 22$ \\
Complete denitrification $\left(\mathrm{N}_{2}\right)^{\mathrm{P}}$ & $103 \pm 19$ & $27 \pm 8$ \\
${\text { Complete denitrification }\left(\mathrm{N}_{2}\right)^{\mathrm{A}}}_{\text {Ammonia oxidation }^{\mathrm{P}}}$ & $15 \pm 2$ & $11 \pm 5$ \\
$\mathrm{~N}_{2} \mathrm{O}$ flux & 57.2 & $\mathrm{ND}$ \\
$\mathrm{N}_{2} \mathrm{O}+\mathrm{N}_{2}$ flux & $74.3^{\mathrm{F}}$ & $\mathrm{ND}$ \\
$\mathrm{N}_{2} \mathrm{O}+\mathrm{N}_{2}$ flux & $153^{\mathrm{F}}$ & $\mathrm{ND}$ \\
\hline
\end{tabular}

Abbreviation: ND, not detected.

(P): potential rates in slurries; (A): rates in intact crusts; (F): maximum fluxes calculated from microprofiles measured after $68 \mathrm{~min}$ of wetting at $1.6-2.4 \mathrm{~mm}(\S)$ and $3-4 \mathrm{~mm}$ depth $\left({ }^{*}\right)$.

for the cyanobacterial and lichen crusts, respectively.

$\mathrm{N}_{2} \mathrm{O}$ profiles from a time-series experiment with cyanobacterial crust pieces revealed a slow increase in $\mathrm{N}_{2} \mathrm{O}$ concentrations in the first $40 \mathrm{~min}$ after addition of water to the crust, followed by a faster progressive increase (Figure 4b). Approximately 3-4 h after wetting, the $\mathrm{N}_{2} \mathrm{O}$ concentrations reached a maximum, after which it decreased (Figure 4c). At a depth of ca. 3-4 mm, an $\mathrm{N}_{2} \mathrm{O}$ concentration peak was observed and thus clearly in the anoxic layer of the crust (Figure $4 \mathrm{~b}$ ). The maximum $\mathrm{N}_{2} \mathrm{O}$ concentration in the crust was as high as $25 \mu_{\mathrm{moll}}^{-1}$. The maximum flux of $\mathrm{N}_{2} \mathrm{O}$ out of the crust, calculated from the linear concentration gradient in the 1.62.4-mm depth interval, was $57.2 \mu \mathrm{mol} \mathrm{N}_{2} \mathrm{O}-\mathrm{N} \mathrm{m}^{-2}$ $\mathrm{h}^{-1}$ (Table 2). The decrease in $\mathrm{N}_{2} \mathrm{O}$ concentrations was faster than their increase and this transient increase followed by a decrease was observed in several incubations (Figures $4 \mathrm{a}$ and $\mathrm{b}$ ). In acetylenetreated crust pieces, a maximum $\mathrm{N}_{2} \mathrm{O}$ concentration of $74.3 \mu \mathrm{moll}^{-1}$ was recorded after $68 \mathrm{~min}$ (Figure $4 \mathrm{~d}$ ). The shape of the $\mathrm{N}_{2} \mathrm{O}$ profiles indicates 
Table 3 Primers used in the quantification of denitrifying and ammonia-oxidizing (AO) genes and the estimated copy number ${ }^{-1}$ of crust

\begin{tabular}{|c|c|c|c|c|c|c|}
\hline \multirow[t]{2}{*}{ Functional group } & \multirow{2}{*}{$\begin{array}{l}\text { Target } \\
\text { gene }\end{array}$} & \multirow[t]{2}{*}{ Primer } & \multirow[t]{2}{*}{ Sequence $\left(5^{\prime}-3^{\prime}\right)$} & \multirow[t]{2}{*}{ Reference } & \multicolumn{2}{|c|}{ Copy number $\mathrm{g}^{-1}$ crust } \\
\hline & & & & & $\begin{array}{c}\text { Cyanobacterial } \\
\text { crust }\end{array}$ & Lichen crust \\
\hline \multirow[t]{2}{*}{ Nitrate reducers } & \multirow[t]{2}{*}{$\operatorname{nar} G$} & narG1960F & TAY GTS GGS CAR GAR AA & $\begin{array}{l}\text { Philippot et al. } \\
\text { (2002) }\end{array}$ & $4.5 \pm 2.2 \mathrm{E}+06$ & $2.2 \pm 0.9 \mathrm{E}+07$ \\
\hline & & narG2650R & TYT CRT ACC ABG TBG C & $\begin{array}{l}\text { Philippot et al. } \\
(2002)\end{array}$ & & \\
\hline \multirow[t]{2}{*}{ Denitrifiers } & \multirow[t]{2}{*}{$\operatorname{nirS}$} & $\mathrm{cd} 3 \mathrm{aF}$ & GTS AAC GTS AAG GAR ACS GG & $\begin{array}{l}\text { Michotey et al. } \\
(2000)\end{array}$ & $8.9 \pm 1.7 \mathrm{E}+06$ & $2.0 \pm 0.1 \mathrm{E}+07$ \\
\hline & & R3cd & GAS TTC GGR TGS GTC TTG A & $\begin{array}{l}\text { Michotey et al. } \\
(2000)\end{array}$ & & \\
\hline \multirow[t]{2}{*}{ Denitrifiers } & \multirow[t]{2}{*}{$\operatorname{nap} A$} & v66 & $\begin{array}{l}\text { TAY TTY YTN HSN AAR ATH ATG } \\
\text { TAY GG }\end{array}$ & $\begin{array}{l}\text { Flanagan et al. } \\
\text { (1999) }\end{array}$ & $6.0 \pm 1.4 \mathrm{E}+07$ & $9.6 \pm 4.1 \mathrm{E}+07$ \\
\hline & & v67 & $\begin{array}{l}\text { DAT NGG RTG CAT YTC NGC CAT } \\
\text { RTT }\end{array}$ & $\begin{array}{l}\text { Flanagan et al. } \\
\text { (1999) }\end{array}$ & & \\
\hline \multirow[t]{2}{*}{$\begin{array}{l}\beta \text {-Proteobacteria } \\
\text { (AO) }\end{array}$} & \multirow[t]{2}{*}{$a m o A$} & amoA1F & GGG GTT TCT ACT GGT GG & $\begin{array}{l}\text { Rotthauwe et al. } \\
\text { (1997) }\end{array}$ & $1.3 \pm 0.1 \mathrm{E}+06$ & $1.6 \pm 0.1 \mathrm{E}+07$ \\
\hline & & amoA2R & CCT CKG SAA AGC CTT CTT C & $\begin{array}{l}\text { Rotthauwe et al. } \\
\text { (1997) }\end{array}$ & & \\
\hline \multirow[t]{2}{*}{$\begin{array}{l}\gamma \text {-Proteobacteria } \\
\text { (AO) }\end{array}$} & \multirow[t]{2}{*}{ amoA } & amoA3F & GGT GAG TGG GYT AAC MG & $\begin{array}{l}\text { Purkhold et al. } \\
(2000)\end{array}$ & $2.9 \pm 0.1 \mathrm{E}+07$ & $2.0 \pm 1.4 \mathrm{E}+08$ \\
\hline & & amoB4R & GCT AGC CAC TTT CTG G & $\begin{array}{l}\text { Purkhold et al. } \\
(2000)\end{array}$ & & \\
\hline \multirow[t]{2}{*}{ Archaeal (AO) } & \multirow[t]{2}{*}{ amoA } & $\begin{array}{l}\text { Arch- } \\
\text { amoAF }\end{array}$ & STA ATG GTC TGG CTT AGA CG & Francis et al. (2005) & \multirow[t]{2}{*}{$9.3 \pm 13.1 \mathrm{E}+07$} & \multirow[t]{2}{*}{$2.6 \pm 2.6 \mathrm{E}+06$} \\
\hline & & $\begin{array}{l}\text { Arch- } \\
\text { amoAR }\end{array}$ & GCG GCC ATC CAT CTG TAT GT & Francis et al. (2005) & & \\
\hline
\end{tabular}

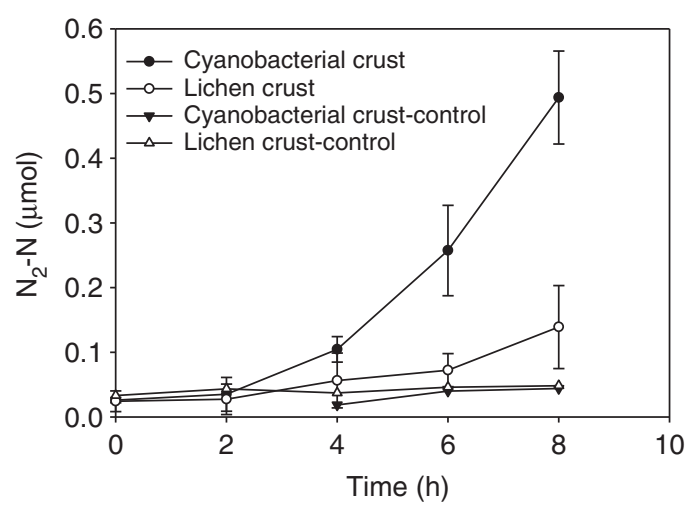

Figure 2 Denitrification activity, measured as $\mathrm{N}_{2}-{ }^{15} \mathrm{~N}$ production over time, in intact crust pieces amended with $25 \mu \mathrm{M}{ }^{15} \mathrm{NO}_{3}^{-}$. The linear increase in $\mathrm{N}_{2^{-}}{ }^{15} \mathrm{~N}$ concentration observed between 4 and $8 \mathrm{~h}$ of incubation was used to calculate the rate of denitrification to $\mathrm{N}_{2}$ per $\mathrm{cm}^{2}$ of crust. All incubations were run in triplicates, and autoclaved crust pieces served as negative controls.

that the layer of $\mathrm{N}_{2} \mathrm{O}$ production was located at a depth of at least $4-5 \mathrm{~mm}$ and thus again clearly in the anoxic layer of the crust (Figure 4d). The maximum flux of $\mathrm{N}_{2} \mathrm{O}$, indicating the total flux of gaseous denitrification products, was $153 \mu \mathrm{mol} \mathrm{N} \mathrm{N}_{2} \mathrm{O}$ $\mathrm{Nm}^{-2} \mathrm{~h}^{-1}$ in the 3-4 mm depth interval (Table 2). The maximum flux of $\mathrm{N}_{2} \mathrm{O}$ out of the crust was $74.3 \mu \mathrm{mol} \mathrm{N}_{2} \mathrm{O}-\mathrm{N} \mathrm{m}^{-2} \mathrm{~h}^{-1}$, as calculated from the linear concentration gradient in the 1.6-2.4-mm depth interval (Table 2).

The relative contribution of $\mathrm{N}_{2} \mathrm{O}$ emission to the total emission of nitrogenous gases was ca. $65 \%$ for

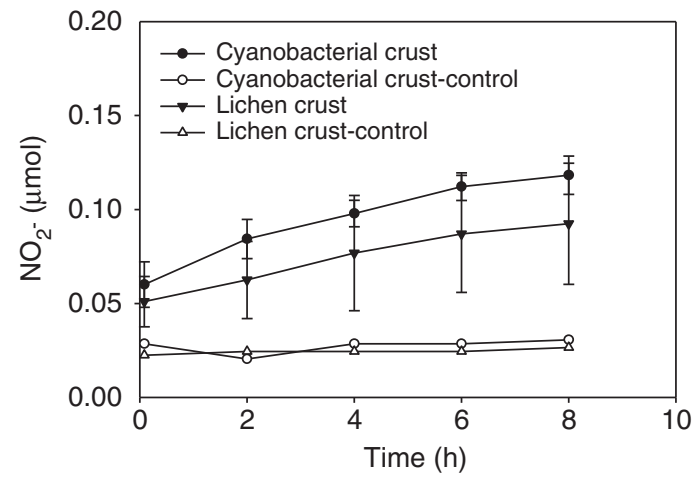

Figure 3 Potential ammonia oxidation activity, measured as $\mathrm{NO}_{2}^{-}$production over time, in slurry incubations of cyanobacterial and lichen crusts amended with $25 \mu \mathrm{M}$ ammonium sulfate $\left(\left(\mathrm{NH}_{4}\right)_{2} \mathrm{SO}_{4}\right)$ and $20 \mathrm{~mm}$ sodium chlorate $\left(\mathrm{NaClO}_{3}\right)$. All incubations were run in triplicates, and autoclaved crust pieces served as negative controls.

$\mathrm{N}_{2} \mathrm{O}$ profiles measured in both the treatments after comparable incubation times (that is, without acetylene: $159 \mathrm{~min}$, with acetylene: $134 \mathrm{~min}$ ) and calculated for the same depth interval (that is, $1.6-2.4 \mathrm{~mm})$.

\section{Abundance and diversity of functional genes}

The functional genes narG, napA and nirS, key to nitrate-reducing and denitrifying bacteria, as well as amo $A$ genes for ammonia-oxidizing bacteria and archaea were detectable in both the cyanobacterial and lichen crusts (Table 3). At the DNA level, the 


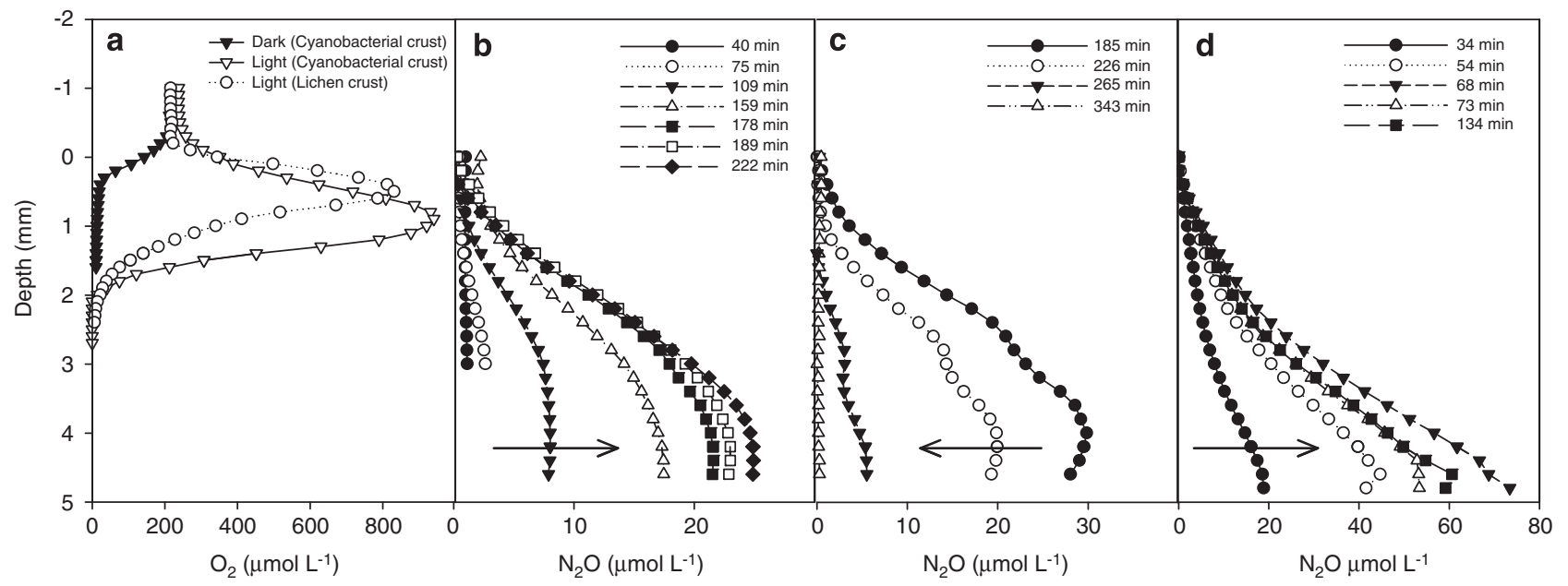

Figure 4 Depth microprofiles of $\mathrm{O}_{2}$ and $\mathrm{N}_{2} \mathrm{O}$ measured in intact cyanobacterial crust pieces using microsensors. (a) $\mathrm{O}_{2}$ profiles in the light and in the dark. (b) $\mathrm{N}_{2} \mathrm{O}$ profiles in a crust piece without the addition of acetylene. The arrow depicts the direction of the increase in $\mathrm{N}_{2} \mathrm{O}$ concentration with time. (c) $\mathrm{N}_{2} \mathrm{O}$ profiles in another crust piece without acetylene showing the decrease in $\mathrm{N}_{2} \mathrm{O}$ concentration after 304 min of measurements. (d) $\mathrm{N}_{2} \mathrm{O}$ profiles in a crust piece after the addition of acetylene.
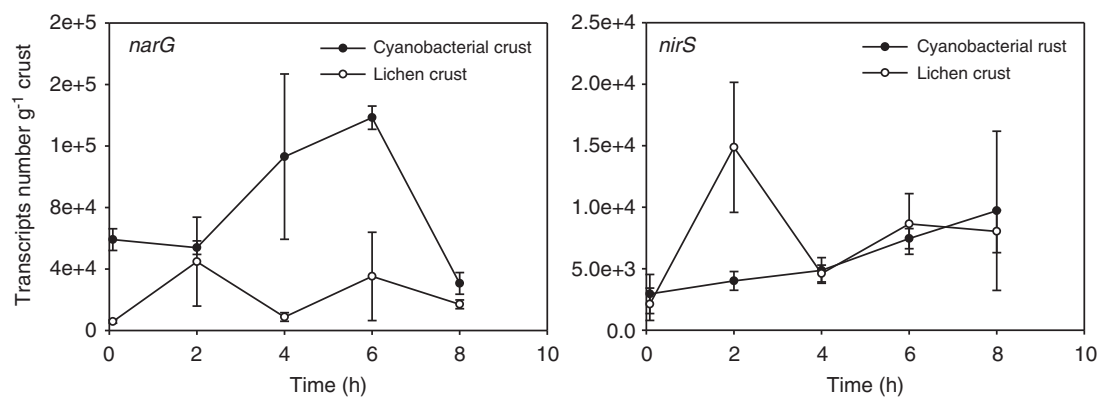

Figure 5 Temporal expression pattern of narG and nirS genes in cyanobacterial and lichen crusts after wetting with water. The estimated transcript number is expressed as the average value of triplicate crust samples at each time point.

copy numbers of the genes narG and nirS were one order of magnitude higher in the lichen crust (Table 3). The gene napA exhibited comparable estimates in both the crusts. Although the amoA genes of Beta- and Gammaproteobacteria were higher in the lichen crust than in the cyanobacterial crust, the opposite was observed for archaeal amo $A$ (Table 3).

At the mRNA level, narG and nirS were expressed at detectable levels after wetting, as detected by RT-qPCR (Figure 5). The cyanobacterial crust displayed slightly higher transcript number of narG than the lichen crust, whereas the numbers of nirS transcripts were comparable in both the crust types. The narG expression increased with time in cyanobacterial crust, reaching its maximum after $6 \mathrm{~h}$, whereas in lichen crust it increased after $2 \mathrm{~h}$ but remained more or less unchanged. The expression of nirS gene showed a general increase with time in both the crust types and reached similar transcript level after $8 \mathrm{~h}$ of incubation, although a maximum of $1.49 \pm 0.5 \times 10^{4}$ transcripts (g crust) $^{-1}$ was reached in $2 \mathrm{~h}$ in the lichen crust (Figure 5).

A total of 13645 and 19361 sequences of nirS and nos $Z$, respectively, were generated after discarding low-quality reads. The numbers of nirS and nosZ sequences were 1178 and 5717 in the cyanobacterial crust and 12467 and 13644 in the lichen crust, respectively (Figure 6). The number of OTUs detected in the cyanobacterial crust was relatively lower than in the lichen crust, which could be due to the variation in sequencing depth. The sequences of nirS genes in the cyanobacterial crusts were assigned to four OTUs based on a 5\% nucleic acids sequence identity cutoff, and $99 \%$ of these sequences (three OTUs) were phylogenetically affiliated to an uncultured denitrifying bacterium from river sediments (HQ882515), with 61-68\% sequence similarity (Figure 6a). The remaining OTU, along with $94 \%$ of the nirS sequences of the lichen crust, was most closely affiliated to the known denitrifying bacterium Paracoccus denitrificans, sharing a maximum sequence similarity of $70 \%$ (Figure 6a). These sequences represented 59 out of a total of 118 OTUs found in the lichen crust. Other nirS sequences in the lichen crust were affiliated to environmental sequences of uncultured denitrifiers, except for one OTU that represented $1.5 \%$ of the total sequences and was related to the nirS gene of Azospirillum (94\% similarity). 
a

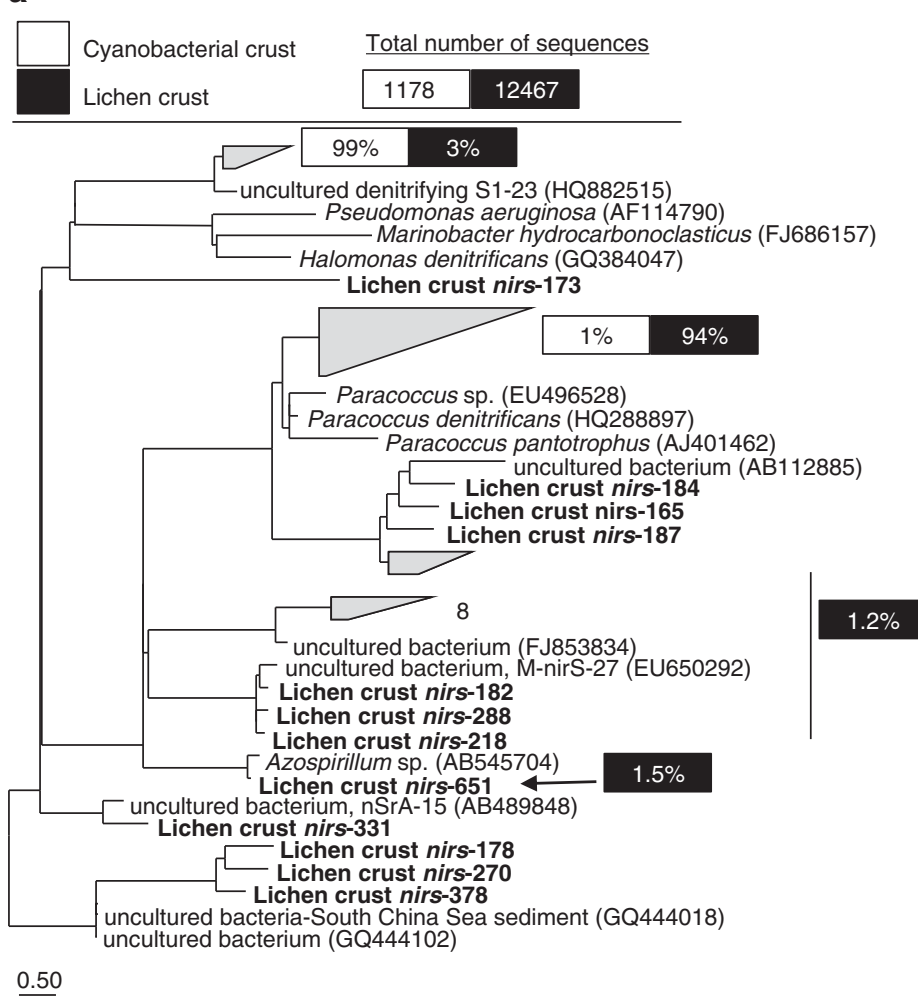

b

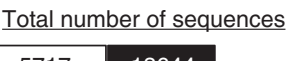

5717

13644

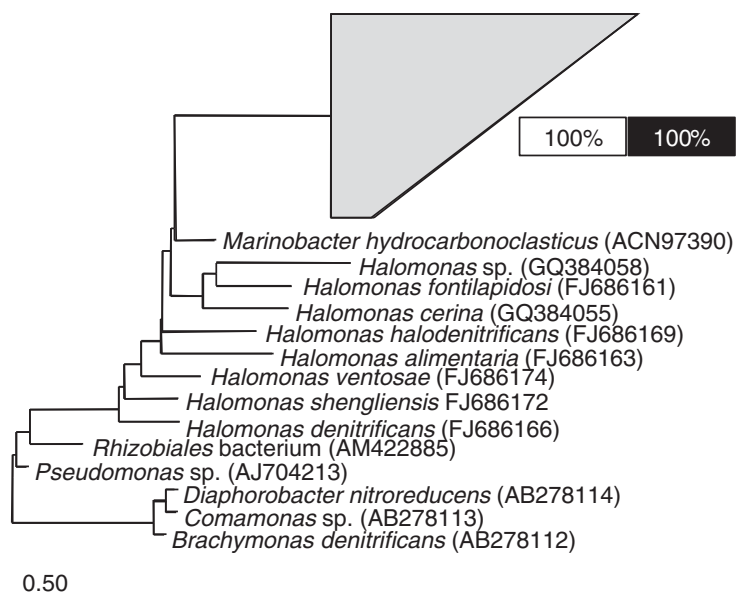

Figure 6 Phylogeny of nirS (a) and nos $Z$ (b) genes in the cyanobacterial and lichen crusts. Phylogenetic affiliations of the crust sequences were determined via maximum parsimony with the quick-add search function in ARB against a consensus tree that has been constructed with all sequences in the database based on maximum likelihood, parsimony and distance matrix algorithms. For clarity, only the crust sequences along with their immediate relatives are shown.

Sequences of the nos $Z$ gene from both the crusts belonged to a total of 574 OTUs and all of them clustered together (Figure 6b). The closest relative to this cluster was a nos $Z$ sequence belonging to Marinobacter hydrocarbonoclasticus, with sequence similarity $\leqslant 66 \%$.

\section{Discussion}

We demonstrated that denitrification, and not anammox, is the major nitrogen loss process in crusts from Oman and that $\mathrm{N}_{2} \mathrm{O}$ gas is emitted during incomplete denitrification. Denitrification rates in crusts from Oman are comparable to those measured in strongly denitrifying freshwater and marine ecosystems (see Table 1 in (Seitzinger, 1988) and references therein), but they were orders of magnitude higher than those reported from other desert crusts (Johnson et al., 2007). Although in our study, the potential denitrification rates of lichen and cyanobacterial crusts, converted to units that match those used in other studies, were equivalent to 805 and $8181 \mu \mathrm{g} \mathrm{N} \mathrm{m}^{-2} \mathrm{~h}^{-1}$, respectively, other authors measured $<0.3 \mu \mathrm{g} \mathrm{N} \mathrm{m}^{-2} \mathrm{~h}^{-1}$ in all the crust types from Colorado Plateau, Sonoran, Chihuahuan and Mojave deserts (Johnson et al., 2007; Strauss and Day, 2012) and $246 \mu \mathrm{g} \mathrm{N} \mathrm{m}^{-2} \mathrm{~h}^{-1}$ in crusts from Great Basin Desert (Burns, 1983). The denitrification rates in Omani crusts were still even higher than those measured in non-crusted desert soils from Sonoran Desert $\left(1160 \mu \mathrm{g} \mathrm{N} \mathrm{m}{ }^{-2} \mathrm{~h}^{-1}\right)$ and Chihuahuan Desert (315 $\mu \mathrm{g} \mathrm{N} \mathrm{m}^{-2} \mathrm{~h}^{-1}$; Virginia et al., 1982; Peterjohn and Schlesinger, 1991). When comparing the potential dentrification rates in the Omani crusts to those reported in other studies, it should be noted that there were differences in the incubation conditions. Although our rates were determined in $\mathrm{NO}_{3}^{-}$ amended slurries for the time interval $4-8 \mathrm{~h}, \mathrm{~N}_{2} \mathrm{O}$ production in Sonoran Desert soils was measured in situ after the addition of distilled water (Virginia et al., 1982), and the measurements in Colorado Plateau, Sonoran, Chihuahuan and Mojave deserts were performed after $4 \mathrm{~h}$ of incubation (Johnson et al., 2007; Strauss and Day, 2012). Slurry incubations typically result in higher rates than incubations under diffusive conditions. This explains the higher potential denitrification rates in the studied crusts compared with the rates calculated from microsensor measurments and from ${ }^{15} \mathrm{NO}_{3}$ incubations. On the other hand, the acetylene inhibition technique used here may underestimate the potential denitrification rates because the acetylene block is alleviated at high sulfide concentrations and acetylene inhibits nitrification (Jones and Knowles, 1992; Sloth et al., 1992). However, in the studied crusts, sulfide could not be measured and $\mathrm{NO}_{3}$ was present in excess and 
hence denitrification did not depend on $\mathrm{NO}_{3}$ supplied by nitrification.

Incubation experiments, microsensor measurements and gene expression analyses consistently showed that denitrification was activated in both the crust types within $2-4 \mathrm{~h}$ after wetting but recovered slightly faster in the cyanobacterial crust. Previous studies, including measurements on the crusts from Oman, showed that other microbial processes also recover rapidly after wetting, with respiration starting immediately within seconds and photosynthesis within minutes to few hours, followed by nitrogen fixation within 2-6h (Isichei, 1980; Scherer et al., 1984; Issa et al., 2001; Abed et al., 2010). The quick recovery of these processes creates an internal microenvironment suitable for denitrification, including the anoxia generated in deeper crust horizons by intense respiration, the release of photosynthetic organic exudates and the continuous supply of nitrate by nitrifying microorganisms (Garcia-Pichel and Belnap, 1996; Johnson et al., 2007). These are also consistent with the slight initial ( $\sim 2 \mathrm{~h}$ ) time lag in the observed $\mathrm{N}_{2}$ production (Figure 2). The $\mathrm{O}_{2}$ microprofiles in the crusts clearly showed the development of anoxia at depths of $0.5 \mathrm{~mm}$ (in the dark) and $2-3 \mathrm{~mm}$ (in the light), below which denitrification activity and the concomitant production of $\mathrm{N}_{2} \mathrm{O}$ could be inferred from $\mathrm{N}_{2} \mathrm{O}$ microprofiles. The higher denitrification rates measured in slurries and in intact cyanobacterial crusts compared with lichen crusts (Table 2) might be explained by the faster recovery of microbial processes in the cyanobacterial crust. This is reflected in the $\mathrm{O}_{2}$ profiles, where maximum net $\mathrm{O}_{2}$ production was reached after 2 and $3.5 \mathrm{~h}$ of wetting in the cyanobacterial and lichen crusts, respectively. Additionally, the somewhat higher $\mathrm{NO}_{3}^{-}$content in the cyanobacterial crust may have enhanced the denitrification activity.

Nitrogen budget: sources and sinks of nitrate Although the low rates of nitrogen loss processes detected in crusts from Colorado Plateau, Mojave, Sonoran and Chihuahuan deserts (Johnson et al., 2007; Strauss and Day, 2012) seemed to indicate net nitrogen gains in these crust systems, the detected nitrogen losses in the Omani crusts well exceeded nitrogen gains instead. Nitrogen-fixation rates previously measured using acetylene reduction assay in our crusts (that is, $183-258 \mu \mathrm{g} \mathrm{N} \mathrm{m}^{-2} \mathrm{~h}^{-1}$, Abed et al., 2010) were comparable with the potential rates of ammonia oxidation (157-208 $\mu \mathrm{g} \mathrm{N} \mathrm{m}^{-2} \mathrm{~h}^{-1}$ ) measured in this study. Thus, nitrification obviously does not represent a bottle-neck between $\mathrm{N}_{2}$ fixation and denitrification. However, both the potential dentrification rates and rates measured in intact crusts were at least 2-10 times higher than the $\mathrm{N}_{2}$-fixation and ammonia oxidation rates. This observation implies either that there were external inputs of nitrate fueling denitrification or that there is indeed a net nitrogen loss occurring in the crusts at the instant of sampling, as previously observed in many river, lake and coastal marine ecosystems (Seitzinger, 1988). When the potential rates of denitrification and nitrification in our crusts are compared, it becomes evident that the nitrate supplied by nitrifying bacteria only constitutes a minor fraction of the nitrate reduced by denitrification. Previously, a temporal decoupling of nitrate inputs and losses has been identified, where most of the nitrogen was fixed during precipitation events in winter and fall and is lost through volatilization during summer (Belnap, 2001). However, in hot deserts such as the Omani desert, $\mathrm{N}$ inputs and losses are likely to occur simultaneously but with much greater $\mathrm{N}$ losses through denitrification and volatilization. As a result, only a very little amount of the newly fixed $\mathrm{N}$ will be available for plants and microbial biomass. Besides nitrification, anthropogenic inputs and aeolian deposition combined with limited hydrological export might lead to accumulation of $\mathrm{NO}_{3}^{-}$inside the crusts (Peterjohn and Schlesinger, 1991; Belnap, 2001). In fact, the initial content of readily available $\mathrm{NO}_{3}^{-}$in the crusts used here was substantial (Table 1) and exceeded the experimentally added $\mathrm{NO}_{3}^{-}$by factors of 3.9-4.7. This in-situ, accumulated $\mathrm{NO}_{3}^{-}$alone would sustain denitrification activity at the rates observed here for about 5.3 and $42 \mathrm{~h}$ in the cyanobacterial and lichen crusts, respectively. Additionally, the two crust types harbored substantial amounts of intracellularly stored $\mathrm{NO}_{3}^{-}$(Table 1). This intracellular $\mathrm{NO}_{3}^{-}$ might sustain denitrification activity for additional 1.5 and $10 \mathrm{~h}$ in the cyanobacterial and lichen crust, respectively. It can thus be expected that under in situ conditions, the rates of denitrification will decrease within 1-2 days after wetting to levels sustained by $\mathrm{NO}_{3}^{-}$production through nitrification, unless $\mathrm{NO}_{3}^{-}$is also externally supplied. The validity of these considerations can be tested by studying the seasonal variations of crustal $\mathrm{NO}_{3}^{-}$accumulation and denitrification rates under in situ conditions. Simultaneous rate measurements of all concurrent $\mathrm{N}$-cycling processes by ${ }^{15} \mathrm{~N}$-labeling experiments would also allow a better comparability among $\mathrm{N}$-fluxes and thus more comprehensive nitrogen budgeting (Holtappels et al., 2011).

\section{$\mathrm{N}_{2} \mathrm{O}$ emission from crusts}

Both the incubation experiments and the direct microsensor measurements demonstrated that the wet crusts from Oman are a significant source of $\mathrm{N}_{2} \mathrm{O}$. In soils and sediments, $\mathrm{N}_{2} \mathrm{O}$ can be produced by both nitrification and denitrification (Meyer et al., 2008). However, our experiments suggest that in the two crust types, $\mathrm{N}_{2} \mathrm{O}$ was entirely produced from incomplete denitrification, as the microsensor profiles clearly showed that $\mathrm{N}_{2} \mathrm{O}$ was exclusively produced in the anoxic zones of the crusts. $\mathrm{N}_{2} \mathrm{O}$ concentrations gradually increased but 
then decreased, as inferred from $\mathrm{N}_{2} \mathrm{O}$ profiles, which may suggest a delayed induction in the expression of nos $Z$ gene, encoding for the last step of denitrification. Potential rate and microsensor measurements with and without acetylene inhibition showed that $\mathrm{N}_{2} \mathrm{O}$ gas made up to $54-66 \%$ of the total produced gases during denitrification in cyanobacterial and lichen crusts, respectively. Measuring the same $\mathrm{N}_{2} \mathrm{O}$ yields in both the experimental settings corroborates the validity of our potential rate measurements. The contribution of $\mathrm{N}_{2} \mathrm{O}$ gas to the total produced nitrogenous gases corresponds to extremely high $\mathrm{N}_{2} \mathrm{O}$ yields by denitrification, which in other ecosystems are in the order of $\leqslant 1 \%$ (Seitzinger, 1988; Bange, 2008). It has previously been suggested that most of the $\mathrm{N}_{2} \mathrm{O}$ produced in semiarid soils is contributed by fungi (Crenshaw et al., 2008), because they lack the enzyme nitrous oxide reductase (Zhou et al., 2001). However, we measured 13 times higher rates of $\mathrm{N}_{2} \mathrm{O}$ emission in the cyanobacterial than in the lichen crusts, suggesting a minimal role of the symbiotic fungi in this process. The potential rate of $\mathrm{N}_{2} \mathrm{O}$ emission in the cyanobacterial crust was as high as $387 \mu \mathrm{mol}$ $\mathrm{m}^{-2} \mathrm{~h}^{-1}$, whereas the $\mathrm{N}_{2} \mathrm{O}$ flux derived from the microsensor profiles was only $52-57 \mu \mathrm{mol} \mathrm{m}^{-2} \mathrm{~h}^{-1}$. This difference in rates can be attributed to the generally higher reaction rates in slurry incubations compared with incubations in which the vertical stratification remains intact and solute transport is diffusion-limited. Regardless of the technique used, the measured $\mathrm{N}_{2} \mathrm{O}$ emission rates were still higher than those of other desert crusts and soils. $\mathrm{N}_{2} \mathrm{O}$ was emitted from soils of the Sonoran Desert at fluxes ranging from 0.4 to $1.88 \mu \mathrm{mol} \quad \mathrm{N}_{2} \mathrm{O}-\mathrm{Nm}^{-2} \mathrm{~h}^{-1}$ (Guilbault and Mathias, 1998) and in Great Basin soils at a rate of $0.005 \mu \mathrm{mol} \quad \mathrm{N}_{2} \mathrm{O}-\mathrm{N} \mathrm{m}^{-2} \mathrm{~h}^{-1}$ (Mummey et al., 1994); however, it was unclear if these soils contained crusts. Field measurements of gaseous losses in wetted crusts from Utah revealed $\mathrm{N}_{2} \mathrm{O}$ emission at a rate of $1.82-3.57 \mu$ mol $\mathrm{N}_{2} \mathrm{O}-\mathrm{N}$ $\mathrm{m}^{-2} \mathrm{~h}^{-1}$ (Belnap, 2001).

\section{Denitrifying bacteria}

The detection of functional genes by qPCR, RT-qPCR and pyrosequencing indicates that denitrifying bacteria are present in both the crusts, thus supporting the observed denitrification activity. Despite the seemingly higher gene abundance of narG, napA and nirS in the lichen crust, the expression of narG was considerably higher in the cyanobacterial crust, which also showed a more steady increase in nirS expression during the 8-h incubation. These might be the result of a somewhat higher $\mathrm{NO}_{3}^{-}$content in the cyanobacterial crust that likely has enhanced denitrification activity (by $>10$ fold) relative to the lichen crust. These gene expression patterns are consistent with the greater denitrification rates measured in cyanobacterial crust compared with the lichen crust. Although the possibility of residual mRNA in dry crusts cannot be fully eliminated especially in view of the detection of narG and nirS transcription after merely 5 min of wetting, the fact that narG and nirS transcripts increased substantially in both the crusts (except for nirS mRNA in lichen crust) with time indicates active gene expression during the incubation periods. The strong and rapid expression of narG and nirS genes corroborates the activities of denitrification at least in the first two steps: nitrate reduction to nitrite and then to nitric oxide. Nitrite may also be reduced by other microorganisms using the copper-containing nitrite reductase (nirK), as nirS and nirK have never been found in the same cell (Zumft, 1997). Despite the attempts made to amplify and sequence nirK via TEFAP, the obtained nirK sequences unfortunately had to be excluded from further analysis because of their low quality. Nevertheless, it should also be noted that nirK has also been found in archaeal and bacterial ammonia oxidizers, as well as an anammox bacterium, as such it is not an ideal biomarker gene for denitrifiers (Cantera and Stein, 2007; Bartossek et al., 2010; Hira et al., 2012).

Complete denitrification through the conversion of $\mathrm{N}_{2} \mathrm{O}$ to $\mathrm{N}_{2}$ in the crusts from Oman was confirmed by the detection of nos $Z$ genes. All these nos $Z$ sequences did not branch with known denitrifying bacteria and only had $<65 \%$ similarity to the closest relatives, indicating their novelty. Similarly, most of the nirS sequences (99\%) retrieved from the cyanobacterial crust and to a lesser extent (4.5\%) from the lichen crust were related to uncultured denitrifying bacteria, thus indicating unique, yet to be cultivated, nitrite reducing/denitrifying communities within these crusts. On the other hand, the majority of nirS sequences in the lichen crust were most closely affiliated to the well-known denitrifiers $P$. denitrificans and Azospirillum, of the Alphaproteobacteria group. The latter, in particular, have previously been detected in the same crusts via pyrosequencing analysis of the 16S rRNA gene (Abed et al., 2010). $P$. denitrificans is mainly found in soils and sewage treatment plants and is nutritionally versatile with a heterotrophic growth mode under aerobic conditions with oxygen and under anaerobic conditions with nitrate as an electron acceptor (Baker et al., 1998). An interesting feature of this organism is its ability to perform denitrification, even in the presence of oxygen (Davies et al., 1989). This makes this organism suitable to survive in compact crusts in which it has to cope with fluctuating conditions of high oxygen concentration due to cyanobacterial photosynthesis during the day and anoxia in the dark.

\section{Environmental implications}

Due to the large global expanse of arid deserts (30-40\% of the Earth's surface), and the Arabian Desert in particular, our findings may have significant 
environmental implications. Our rate measurements indicate that desert crusts produce and emit $\mathrm{N}_{2} \mathrm{O}$ gas immediately after wetting and thereby might contribute to the greenhouse effect, the destruction of the protecting ozone layer in the stratosphere and rainfall acidity (Dickinson and Cicerone, 1986; Cicerone, 1987). However, the magnitude of these effects can only be judged after obtaining information on the coverage of crusts, the frequency of precipitation events and how long the crusts retain their moisture and the rates of denitrification and nitrous oxide emission under field conditions. It can further be speculated that the high loss of fixed nitrogen through denitrification relative to nitrogen inputs in the Arabian Desert may significantly exacerbate the fertility of the desert soil. This nitrogen cycling pattern in the Arabian Desert poses a serious threat to desert life, and nitrogen losses may even increase with the observed changes in temperature and precipitation patterns due to global climate changes (McCalley and Sparks, 2009).

\section{Conflict of Interest}

The authors declare no conflict of interest.

\section{Acknowledgements}

We thank the Hansewissenschaftskolleg, Institute for Advanced Studied in Delmenhorst, Germany for supporting RA. We also thank the technicians of the Microsensor Group of the Max Planck Institute for Marine Microbiology in Bremen for microsensor construction. This research was funded by The Research Council (TRC) of Oman (Grant No. RC/SCI/BIOL/11/01) and the Max-Planck Society.

\section{References}

Abed RMM, Kharusi SA, Schramm A, Robinson MD. (2010). Bacterial diversity, pigments and nitrogen fixation of biological desert crusts from the Sultanate of Oman. FEMS Microbiol Ecol 72: 418-428.

Allan JA, Warren A. (1993). Deserts: The Encroaching Wilderness: A World Conservation Atlas. Oxford University Press: New York, NY, USA.

Altschul SF, Madden TL, Schäffer AA, Zhang J, Zhang Z, Miller W et al. (1997). Gapped BLAST and PSI-BLAST: a new generation of protein database search programs. Nucleic Acids Res 25: 3389-3402.

Andersen K, Kjaer T, Revsbech NP. (2001). An oxygen insensitive microsensor for nitrous oxide. Sens Actuators $B$ Chem 81: 42-48.

Angel R, Matthies D, Conrad R. (2011). Activation of methanogenesis in arid biological soil crusts despite the presence of oxygen. PLoS One 6: 1-7.

Austin AT, Yahdjian L, Stark JM, Belnap J, Porporato A, Norton U et al. (2004). Water pulses and biogeochemical cycles in arid and semiarid ecosystems. Oecologia 141: 221-235.

Baker SC, Ferguson SJ, Ludwig B, Page MD, Richter OM, Spanning RJ. (1998). Molecular genetics of the genus Paracoccus: metabolically versatile bacteria with bioenergetic flexibility. Microbiol Mol Biol Rev 62: 1046-1078.

Bange HW. (2008). Gaseous nitrogen compounds (NO, $\mathrm{N}_{2}$, $\mathrm{NH}_{3}$ ) in the ocean. In: Capone DG, Bronk DA, Mulholland MR, Carpenter EJ (eds). Nitrogen in the Marine Environment. Elsevier Press: Amsterdam, The Netherlands, pp 51-94.

Barger NN, Belnap J, Ojima D, Mosier A. (2005). NO gas loss from N-fixing biologically crusted soils in Canyonlands National Park, Utah. Biogeochemistry 75: 373-391.

Bartossek R, Nicol GW, Lanzen A, Klenk H-P, Schleper C. (2010). Homologues of nitrite reductases in ammoniaoxidizing archaea: diversity and genomic context. Environ Microbiol 12: 1075-1088.

Belnap J. (2001). Factors influencing nitrogen fixation and nitrogen release in biological soil crusts. In: Belnap J, Lange OL (eds). Biological Soil Crusts: Structure, Function, and Management. Springer-Verlag: Berlin, Germany, pp 241-261.

Belnap J. (2002). Nitrogen fixation in biological soil crusts from southeast Utah, USA. Biol Fertil Soils 35: 128-135.

Belnap J. (1995). Recovery of nitrogenase activity in cyanobacterial-lichen soils crusts of the Great Basin and the Colorado Plateau. In: The Transdisciplinary Nature of Ecology 1995; Snowbird, Utah, USA.

Belser LW, Mays EL. (1980). Specific inhibition of nitrite oxidation by chlorate and its use in assessing nitrification in soils and sediments. Appl Environ Microbiol 39: 505-510.

Billings SA, Schaeffer SM, Evans RD. (2003). Nitrogen fixation by biological soil crusts and heterotrophic bacteria in an intact Mojave Desert ecosystem with elevated $\mathrm{CO}_{2}$ and added soil carbon. Soil Biol Biochem 35: 643-649.

Braman RS, Hendrix SA. (1989). Nanogram nitrite and nitrate determination in environmental and biological materials by vanadium(III) reduction with chemiluminescence detection. Anal Chem 61: 2715-2718.

Burns SJ. (1983). Nitrogen fixation and transformations in cryptogamic soil crusts as affected by disturbance. MSc thesisBrigham Young University: Provo, UT, USA.

Cantera JJL, Stein LY. (2007). Molecular diversity of nitrite reductase genes (nirK) in nitrifying bacteria. Environ Microbiol 9: 765-776.

Cicerone RJ. (1987). Changes in stratospheric zone. Science 237: 35-42.

Crenshaw CL, Lauber C, Sinsabaugh RL, Stavely LK. (2008). Fungal control of nitrous oxide production in semiarid grassland. Biogeochemistry 87: 17-27.

Davies KJP, LLoyd D, Boddy L. (1989). The effect of oxygen on denitrification in Paracoccus denitrificans and Pseudomonas aeruginosa. J Gen Microbiol 135: 2445-2451.

Dickinson RE, Cicerone RJ. (1986). Future global warming from atmospheric trace gases. Nature 319: 109-115.

Dowd SE, Callaway TR, Wolcott RD, Sun Y, McKeehan T, Hagevoort RG et al. (2008b). Evaluation of the bacterial diversity in the feces of cattle using $16 \mathrm{~S}$ rDNA bacterial tag-encoded FLX amplicon pyrosequencing (bTEFAP). BMC Microbiol 8: 125.

Dowd SE, Sun Y, Wolcott RD, Domingo A, Carroll JA. (2008a). Bacterial tag encoded FLX amplicon pyrosequencing (bTEFAP) for microbiome studies: bacterial 
diversity in the ileum of newly weaned Salmonellainfected pigs. Foodborne Pathog Dis 5: 459-472.

Edgar RC. (2004). MUSCLE: multiple sequence alignment with high accuracy and high throughput. Nucleic Acids Res 32: 1792-1797.

Flanagan DA, Gregory LG, Carter JP, Karakas-Sen A, Richardson DJ, Spiro S. (1999). Detection of genes for periplasmic nitrate reductase in nitrate respiring bacteria and in community DNA. FEMS Microbiol Lett 177: $263-270$.

Francis CA, Roberts KJ, Beman JM, Santoro AE, Oakley BB. (2005). Ubiquity and diversity of ammoniaoxidizing archaea in water columns and sediments of the ocean. Proc Natl Acad Sci USA 102: 14683-14688.

Gao K, Qui B, Xia J, Yu A. (1998). Light dependency of the photosynthetic recovery of Nostoc flagelliforme. J Appl Phycol 10: 51-53.

Garbauer RL, Ehleringer JR. (2000). Water and nitrogen uptake patterns following moisture pulses in a cold desert community. Ecology 81: 1415-1424.

Garcia-Pichel F, Belnap J. (1996). Microenvironments and microscale productivity of cyanobacterial desert crusts. I Phycol 32: 774-782.

Guilbault MR, Mathias AD. (1998). Emissions of $\mathrm{N}_{2} \mathrm{O}$ from Sonoran desert and effluent-irrigated grass ecosystems. J Arid Environ 38: 87-98.

Hira D, Toh H, Migita CT, Okubo H, Nishyama T, Hattori M et al. (2012). Anammox organism KSU-1 expresses a nirK-type copper-containing nitrite reductase instead of a nirS-type with cytochrome cd. FEBS Lett 586: 1658-1663.

Holtappels M, Lavik G, Jensen MM, Kuypers MMM. (2011). ${ }^{15} \mathrm{~N}$-labeling experiments to dissect the contributions of heterotrophic denitrification and anammox to nitrogen removal in the OMZ waters of the ocean. Methods Enzymol 486: 223-251.

Humbert S, Tarnawski S, Fromin N, Mallet M-P, Aragno M, Zopfi J. (2010). Molecular detection of anammox in bacteria in terrestrial ecosystems: distribution and diversity. ISME J 4: 450-454.

Isichei AO. (1980). Nitrogen fixation by blue-green algal soil crusts in Nigerian savanna. In: Rosswall $\mathrm{T}$ (ed). Nitrogen Cycling in West African Ecosystems. Reklam and Katalogtryck: Uppsala, Sweden, pp 191-198.

Issa OM, Stal LJ, Défarge C, Couté A, Trichet J. (2001). Nitrogen fixation by microbial crusts from desiccated Sahelian soils (Niger). Soil Biol Biochem 33: 1425-1428.

Johnson SL, Budinoff CR, Belnap J, Garcia-Pichel F. (2005). Relevance of ammonium oxidation within biological soil crust communities. Environ Microbiol 7: 1-12.

Johnson SL, Neuer S, Garcia-Pichel F. (2007). Export of nitrogenous compounds due to incomplete cycling within biological soil crusts of arid lands. Environ Microbiol 9: 680-689.

Jones AM, Knowles R. (1992). Sulfide alleviation of acetylene inhibition of nitrous oxide reduction by Flexibacter canadensis. Can J Microbiol 38: 143-148.

Kamp A, de Beer D, Nitsch JL, Lavik G, Stief P. (2011). Diatoms respire nitrate to survive dark and anoxic conditions. Proc Natl Acad Sci USA 108: 5649-5654.

Kempers AJ, Kok CJ. (1989). Re-examination of the determination of ammonium as the indophenol blue complex using salicylate. Anal Chim Acta 221: 147-155.
Kuypers MMM, Lavik G, Woebken D, Schmid M, Fuchs BM, Amann R et al. (2005). Massive nitrogen loss from the Benguela upwelling system through anaerobic ammonium oxidation. Proc Natl Acad Sci USA 102: 64786483.

Kuypers MMM, Olav Sliekers A, Lavik G, Schmid M, Jørgensen BB, Gijs Kuenen J et al. (2003). Anaerobic ammonium oxidation by anammox bacteria in the Black Sea. Nature 422: 608-611.

Lam P, Kuypers MMM. (2011). Microbial nitrogen cycling processes in oxygen minimum zones. Ann Rev Mar Sci 3: 317-345.

Lam P, Lavik G, Jensen MM, Vossenberg J, Schmid M, Woebken D et al. (2009). Revising the nitrogen cycle in the peruvian oxygen minimum zone. Proc Natl Acad Sci USA 106: 4752-4757.

Ludwig W, Strunk O, Westram R, Richter L, Meier H, Yadhukumar et al. (2004). ARB: a software environment for sequence data. Nucleic Acids Res 32: 1363-1371.

McCalley CK, Sparks JP. (2009). Abiotic gas formation drives nitrogen loss from a desert ecosystem. Science 326: 837-840.

McNeill A, Unkovich M. (2007). The Nitrogen cycle in terrestrial ecosystems. In: Marschner P, Rengel Z (eds). Nutrient Cycling in Terrestrial Ecosystems. Springer Verlag: Berlin, Heidelberg, Germany, pp 37-64.

Meyer RL, Allen DE, Schmidt S. (2008). Nitrification and denitrification as sources of sediment nitrous oxide production: a microsensor approach. Mar Chem 110: 68-76.

Michotey V, Meijean V, Bonin P. (2000). Comparison of methods for quantification of cytochrome cd1-denitrifying bacteria in environmental marine samples. Appl Environ Microbiol 66: 1564-1571.

Mummey DL, Smith JL, Bolton H. (1994). Nitrous oxide flux from a shrub-steppe ecosystem: sources and regulation. Soil Biol Biochem 26: 279-286.

Muyi C, Caldwell MM. (1997). A large ephemeral release of nitrogen upon wetting of dry soil and corresponding root responses in the field. Plant Soil 191: 299.

Nielsen LP. (1992). Denitrification in sediment determined from nitrogen isotope pairing. FEMS Microbiol Lett 86: 357-362.

Peterjohn WT, Schlesinger WH. (1991). Factors controlling denitrification in a Chihuahuan Desert ecosystem. Soil Sci Soc Am J 55: 1694-1701.

Philippot L, Piutti S, Martin-Laurent F, Hallet S, Germon JC. (2002). Molecular analysis of the nitrate-reducing community from unplanted and maize-planted soils. Appl Environ Microbiol 68: 6121-6128.

Polerecky L, Bachar A, Schoon R, Grinstein M, Jørgensen BB, de Beer D et al. (2007). Contribution of Chloroflexus respiration to oxygen cycling in a hypersaline microbial mat from Lake Chiprana, Spain. Environ Microbiol 9: 2007-2024.

Poth M. (1986). Dinitrogen production from nitrite by a Nitrosomonas isolate. Appl Environ Microbiol 52: 957-959.

Purkhold U, Wagner W, Timmermann G, PommereningRöser A, Koops H-P. (2000). Phylogeny of all recognized species if ammonia oxidizers based on comparative 16S rRNA and amoA sequence analysis: implications for molecular diversity surveys. Appl Environ Microbiol 66: 5368-5382.

Qiu B, Gao K. (1999). Dried field populations of Nostoc flagelliforme (Cyanophyceae) require exogenous 
nutrients for their photosynthetic recovery. I Appl Phycol 11: 535-541.

Qiu BS, Zhang AH, Liu ZL, Gao KS. (2004). Studies on the photosynthesis of the terrestrial cyanobacterium Nostoc flagelliforme subjected to desiccation and subsequent rehydration. Phycologia 43: 521-528.

Revsbech NP. (1989). An oxygen microsensor with a guard cathode. Limnol Oceanogr 34: 474-478.

Ritchie GAF, Nicholas DJD. (1972). Identification of nitrous oxide produced by oxidative and reductive processes in Nitrosomonas europaea. Biochem $J$ 126: 1181-1191.

Rotthauwe J-H, Witzel k-P, Liesack W. (1997). The ammonia monooxygenase strcutural gene amoA as a functional marker: molecular fine-scale analysis of natural ammonia oxidizing populations. Appl Environ Microbiol 63: 4704-4712.

Santoro AE, Buchwald C, McIlvin MR, Casciotti KL. (2011). Isotopic signature of $\mathrm{N}_{2} \mathrm{O}$ produced by marine ammonia-oxidizing archaea. Science 333: 1282-1285.

Scherer S, Ernst A, Chen T-W, Böger P. (1984). Rewetting of drought-resistant blue green algae: time course of water uptake and reappearance of respiration, photosynthesis, and nitrogen fixation. Oecologia 62: 418-423.

Schloss PD, Westcott SL, Ryabin T, Hall JR, Hartmann M, Hollister EB et al. (2009). Introducing mothur: open source, platform-independent, community supported software for describing and comparing microbial communities. Appl Environ Microbiol 75: 7537-7541.

Schmidt I, van Spanning RJM, Jetten MSM. (2004). Denitrification and ammonia oxidation by Nitrosomonas europaea wild-type, and NirK- and NorB-deficient mutants. Microbiol 150: 4107-4114.

Seitzinger SP. (1988). Denitrification in freshwater and coastal marine ecosystems: ecological and geochemical significance. Limnol Oceanogr 33: 702-724.

Sloth NP, Nielsen LP, Blackburn TH. (1992). Nitrification in sediment cores measured with acetylene inhibition. Limnol Oceanogr 37: 1108-1112.

Stief P, de Beer D. (2006). Probing the microenvironment of freshwater sediment macrofauna: implications of deposit-feeding and bioirrigation for nitrogen cycling. Limnol Oceanogr 51: 2538-2548.

Strauss SL, Day TA. (2012). Nitrogen cycling in desert biological soil crusts across biogeographic regions in the Southwestern United States. Biogeochemistry 108: 171-182.

Sørensen J. (1978). Occurrence of nitric and nitrous oxides in a coastal marine sediment. Appl Environ Microbiol 36: 809-813.

Ullman WJ, Aller RC. (1982). Diffusion coefficients in nearshore marine sediments. Limnol Oceanogr 27: $552-556$.

Veluci RM, Neher DA, Weicht TR. (2006). Nitrogen fixation and leaching of biological soil crust communities in mesic temperate soils. Microb Ecol 51: 189-196.

Virginia RA, Jarrell WM, Franco-Vizcaino E. (1982). Direct measurement of denitrification in a Priosopis (Mesquite) dominated Sonoran Desert ecosystem. Oecologia 53: 120-122.

Ward BB, Devol AH, Rich JJ, Chang BX, Bulow SE, Naik H et al. (2009). Denitrification as the dominant nitrogen loss process in the Arabian Sea. Nature 461: 78-82.

Wrage N, Velthof GL, Beusichem MLV, Oenema O. (2001). Role of nitrifier denitrificaiton in the production of nitrous oxide. Soil Biol Biochem 33: 1723-1732.

Yang F, Troncy E, Francoeur M, Vinet B, Vinay P, Czaika G et al. (1997). Effects of reducing reagents and temperature on conversion of nitrite and nitrate to nitric oxide and detection of NO by chemiluminescence. Clin Chem 43: 657-662.

Yeager CM, Kornosky JL, Housman DC, Grote EE, Belnap J, Kuske C. (2004). Diazotrophic community structure and function in two successional stages of biological soil crusts from the Colorado Plateau and Chihuahuan desert. Appl Environ Microbiol 70: 973-983.

Zhou A, Takaya N, Sakairi MAC, Shoun H. (2001). Oxygen requirement for denitrification by the fungus Fusarium oxysporum. Arch Microbiol 175: 25.

Zumft WG. (1997). Cell biology and molecular basis of denitrification. Microbiol Mol Biol Rev 61: 533-616. 